\title{
KONSTRUKSI GENDER DALAM PERKAWINAN “NYAKAK” DAN “SEMANDA” DI MASYARAKAT ADAT SAIBATIN LAMPUNG
}

\author{
Dasrun Hidayat \\ Doctoral Students, University of Padjadjaran Bandung Indonesia \\ Lecturer of Communication Studies University of BSI Bandung Indonesia
}

dasrun.duh@bsi.ac.id

ABSTRACT

This study focuses on the marital status Nyakak construction and Semanda in customary marriage Saibatin society. Construction of the meaning of the marital status through a gender perspective. Saibatin recognize three types of marital status; (1) marriage Nyakak, (2) the marriage Semanda, (3) and marriage Kings. The study used a qualitative approach to the constructivist paradigm and methods of phenomenology. Saibatin informant indigenous peoples who undergo marital status Semanda and Nyakak Sukabanjar Lampung village. The study states that indigenous peoples Saibatin Lampung, more familiar forms of marital status Nyakak and Semanda. Marital status used as one of the conditions determining customary title or Juluk Adok the bride and groom. Saibatin society, explicitly recognize patriarchal lines or following the path of man, so that after marriage the wife came home with the husband's family or customary terms Saibatin namely Nyakak. While the application of marriage Semanda, know matrilineal system, after marriage the husband follows the lines and kinship status wife. All related roles and responsibilities of the material as well as customs automatically switch family wife. Nyakak marriage and Semanda occur due to several factors such as economic status, parents have many children, all children consisting of all female or all male, child, first child and for not getting permission from parents. Marital status Kings today become an alternative for indigenous communities Saibatin. They decided this as a gesture of rights and the same responsibilities, so that they do not wish to be bound by or among the family of marital status. Marriage Kings is rated as a solution in the middle of gender dominiasi between family men and women.

Keywords: Nyakak, Semanda, Kings, Gender, Take the Kids. 
Introduction

Gender merupakan telaah yang selalu menarik untuk didiskusikan karena gender adalah kajian yang mencoba mengkonstruksi tentang peran laki-laki dan perempuan di masyarakat. Namun, yang paling menonjol dalam kajian realitas gender tersebut yaitu peran kaum feminis yang disebut feminisem atau gerakan perempuan yang memperjuangkan keadilan bagi perempuan. Situasi ini didorong oleh budaya patriariki yakni budaya yang menempatkan laki-laki pada bagian pertama sehingga dapat menimbulkan bias gender, mengsubordinasikan perempuan dari laki-laki atau menjadikan perempuan sebagai status sekunder, kelas kedua setelah laki-laki.

Fenomena tentang bias gender atau menempatkan perempuan pada kelas sekunder juga terjadi pada penetapan status perkawinan. Seperti halnya masyarakat adat Saibatin Lampung memiliki pemahaman tersendiri tentang cara dan memilih status perkawinan. Secara turun-temurun mereka mengikuti perkawinan adat dengan ketentuan status perkawinan Nyakak, Semanda dan Raja-Raja. Nyakak yakni status perkawinan yang mengikuti jalur kekerabatan suami. Perkawinan Semanda artinya suami mengikuti jalur kekerabatan isteri. Perkawinan Raja-Raja memposisikan status berada ditengah-tengah kedua keluarga, sehingga anak yang telah menikah memiliki tanggung jawab dan peran yang ganda. Demikian pula orang tua mereka, mempunyai kewajiban untuk memberikan bekal berupa materi apabila mampu. Raja-Raja merupakan status perkawinan yang akhir-akhir ini menjadi trend karena mulai dipilih oleh pasangan yang akan menikah.

Status perkawinan yang selama ini dijalankan oleh masyarakat adat Saibatin, bisa jadi diterapkan pula di daerah lainnya. Misalnya status perkawinan di Minang Kabau Sumatera Barat (Azima: 2013) The Minangkabau's Customary Land: The Role of "Orang Semenda" in Malaysia and Indonesia menjelaskan bahwa orang Minang mengenal jalur kekerabatan isteri atau matrilinial sehingga setiap suami yang menikahi perempuan Minang harus ikut pulang ke rumah keluarga isteri. Akan tetapi, yang membedakan dengan masyarakat adat Saibatin, adalah mereka memiliki kelonggaran dalam menentukan status 
perkawinan. Jika pada mulanya adat Saibatin sangat kental dengan aristokrasinya ketika menentukan status adat perkawinan, maka saat ini relatif lebih demokratis. Di satu sisi Lampung memang menganut sistem kekerabatan suami atau patriarki, namun di sisi lain memberikan kelonggaran bagi anaknya untuk memilih status perkawinan mereka seperti kekerabatan matrilinial yang tercermin pada perkawinan Semanda atau netral pada perkawinan Raja-Raja. Masyarakat adat Saibatin, menilai bahwa menetapkan status perkawinan itu sangat penting karena berkaitan dengan gelar adat atau Juluk-Adok yang akan diterima oleh kedua mempelai. Jika status perkawinan Nyakak yang dipilih, maka status kekerabatan dan adat istiadat mengikuti keluarga suami. Demikian pula seterusnya.

Menentukan status perkawinan dipengaruhi oleh banyak faktor, seperti faktor ekonomi, jumlah anak dan kesepakatan setiap anggota keluarga serta tidak dipungkiri pula adanya faktor sakit hati dan keterpaksaan karena keluarganya mengalami brokenhome akibat dari perceraian orangtua atau orangtua telah meninggal dunia sejak mereka kecil (sanak hakhuk). Faktor-faktor tersebut acap kali mendorong calon pasangan suami-isteri lebih memilih status perkawinan Nyakak dan Semanda. Mereka menilai status perkawinan Nyakak dan Semanda diharapkan dapat mengobati rasa sakit hati dengan menemukan keluaga baru yang dapat menerima kehadirannya. Mereka mengetahui bahwa Nyakak dan Semanda secara tidak langsung menghilangkan status kekerabatan sebelumnya dan berpindah kepada sistem kekerabatan suami jika memilih Nyakak atau isteri apabila memilih Semanda.

Status perkawinan Nyakak dan Semanda memiliki tanggung jawab yang besar yakni menggantikan peran dari orangtua mertua. Mengelola semua urusan kekerabatan suami atau isteri dan adat istiadat yang sudah ada di dalam lamban balak atau rumah besar, seperti halnya rumah gadang di Minang yakni rumah tempat berkumpulnya keluarga besar. Semua terkait dengan kekerabatan dan adat diambil alih dan dikuasai oleh keluarga pihak isteri atau suami. Misalnya, laki-laki yang memilih Semanda, secara tidak langsung telah menyerahkan dirinya secara utuh kepada pihak keluarga isteri. Mengikuti semua aturan 
yang ada dipihak isteri, bahkan secara otomatis terbebaskan dari tanggung jawab terhadap keluarga kandungnya seperti orang tua dan adik atau kakaknya. Status keturunan pun tidak dilihat dari jalur suami atau ayah, akan tapi mengikuti jalur keturunan ibu atau isteri.

Fenomena yang dijelaskan pada bagian sebelumnya, merupakan alasan yang mendasari penelitian ini. Peneliti bermaksud untuk mengetahui pengalaman dan pemahaman orang-orang yang saat ini menjalankan status perkawinan Nyakak dan Semanda. Terdapat banyak makna yang dapat dikonstruksi secara bersama atau intersubjective sehingga dapat diketahui makna-makna yang terkandung dalam perkawinan, status perkawinan Nyakak dan Semanda dan bagaimana secara individu menjalani dan mengakui bahwa dirinya berstatus tersebut. Oleh karena itu, penelitian ini akan melakukan teknik wawancara mendalam sehingga cara tersebut diharapkan dapat menjawab kebutuhan penelitian. Penelitian menggunakan pendekatan kualitatif, paradigma konstruktivis dan metode fenomenologi ini, peneliti dapat menggali data dan mengolah data mulai dari bracketing atau menyusun serta mengelompokkan data, intuiton yakni mencoba untuk mendisplay dengan menghubungkan antar data dan describing yaitu mencoba mendeskripsikan atau membuat naskah narativ atas data tersebut. Diharapkan data-data tersebut dapat disusun secara sistematis dan terangkai menjadi makna-makna yang berarti. Secara praktis penelitian ini semoga dapat bermanfaat bagi para pelaku perkawinan status Nyakak dan Semanda dalam menyikapi atau memaknai kehidupan mereka. Memposisikan yang tepat dan tidak memaksakan yang tidak semestinya terjadi.

\section{Problem Statement}

Mengacu pada penjelasan pada konteks penelitian maka fokus yang diambil pada penelitian ini adalah "Bagaimana mengkonstruksi status perkawinan Nyakak dan Semanda berdasarkan perspektif gender?". Gender sangat kental dalam dua status perkawinan tersebut. Nyakak memposisikan perempuan yang dikuasia oleh keluarga suami, dan sama halnya dengan status Semanda, laki-laki dikuasai atau diambil alih oleh keluarga isteri. Namun, penelitian ini tidak bermaksud untuk mengkritisi adat istiadat status perkawinan 
tersebut, akan tetapi lebih kepada bagaimana masyarakat adat Saibatin memahami dan menjalankan status perkawinan Nyakak dan Semanda. Pemaknaan status perkawinan Nyakak dan Semanda mencoba mengkonstruksi kembali makna-makna secara holistik tentang motif-motif atau alasan memilih status perkawinan dan struktur diri dari laki-laki dan perempuan berstatus perkawinan Nyakak dan Semanda.

\section{Metodologi Penelitian}

Berangkat dari fokus dan tujuan penelitian tentang konstruksi status perkawinan Nyakak dan Semanda, dengan maksud memahami tentang makna-makna dibalik status perkawinan tersebut, maka penelitian ini memilih menggunakan paradigma konstruktivis dan metode fenomenologi. Menurut Miller (2005:35-80) mengajukan tipologi yang mencakup empat paradigma yaitu Positivism, Postpositivism, Critical Theories dan Constructivism. Masing - masing paradigma memiliki implikasi metodologi tersendiri. Tetapi sejumlah ilmuwan sosial lain melihat positivism dan postpositivism bisa disatukan sebagai classical paradigm karena dalam prakteknya implikasi metodologi keduanya tidak jauh berbeda. Karena itu pula untuk kepentingan mempermudah bahasan tentang implikasi metodologi dari suatu paradigma, maka teori-teori dan penelitian ilmiah komunikasi cukup dikelompokkan kedalam dua paradigma, yakni : (1) Clasical paradigm yang mencakup positivism dan postpositivism), (2) alternative paradigm meliputi critical paradigm, dan consturctivism paradigm.

Metode merupakan cara bagaimana peneliti menggali dan mendaptkan data terkait masalah penelitian. Dalam hal ini peneliti menggunakan metode fenomenologi. Menurut Peter Berger dan Thomas Luckmann (1966) dalam Denzin (2009: 336) bahwa fenomenologi merupakan realita yang terkonstruksi secara sosial. Pengembangan praktik interpretif sebagai cara bagaimana objektivitas dunia terjadi dan diatur secara lokal dengan merujuk pada berbagai sumber luar, baik yang bersifat organisasional, sosial, maupun kultur, sehingga mengaitkan terma yang 
disebut Garfinkel sebagai kepiawaian dengan struktur interpretif yang sudah mapan. Denzin (2009: 336).

Prinip-prinsip fenomenologis; pendekatan penelitian praktik interpretif memiliki sederet asumsi subjektivis tentangan hakikat pengalaman nyata dan tatanan sosial. Pendekatan tersebut mengingatkan kita pada upaya Alfred Schutz dalam membangun fenomenologi sosial yang mengaitkan sosiologi dengan fenomenologi filosofinya Edmund Husserl. Menurut Husserl, ilmu pengetahuan selalu berpijak pada yang eksperiensial (yang bersifat pengalaman). Hubungan antara persepsi dengan objek-objeknya tidaklah pasif. Melainkan bahwa kesaaran manusia secara aktif mengandung objek-objek pengalaman. Bahwa prilaku membentuk realitas. Schutz menekankan bahwa kesadaran dan interaksi bersifat saling membentuk. Perspektif subjektif interpretiv merupakan satu-satunya jaminan yang perlu dipertahankan agar dunia realtias sosial tidak akan pernah digantikan dengan dunia fiktif yang bersifat semu yang diciptakan oleh para peneliti ilmiah. Dalam pandangan ini, subjektivitas adalah satu-satunya prinsip yang tidak boleh dilupakan ketika para peneliti sosial memaknai objek-objek sosial.

Schutz dan Luckman dalam Denzin, Lincoln (2009:337) menjelaskan bahwa fenomenologi menekankan bagaimana orang-orang yang berhubungan dengan objek-objek pengalaman memahami dan berinteraksi dengan objek tersebut sebagai "benda yang terpisah dari sang peneliti. Pengetahuan sebagai bekal dan sebagai sumber yang memungkinkan setiap individu untuk menginterpretasi pengalaman, memahami maksud dan motivasi individu lain, memperoleh pemahaman intersubjektif dan pada akhirnya mengupayakan tindakan. Schutz memandang bahwa pengalaman dan motivasi individu mendorong adanya kesadaran yang didasari oleh faktor motif yaitu because motive atau yaitu alasan, historis, latar belakang individu dan in order to motive; yaitu alasan tentang apa yang akan dicapai, keinginan individu. Kesadaran individu cenderung melakukan tifikasi atau pemolaan, bahasa merupakan sarana utama untuk melakukan transmisi pemolaan dan sebagai akibatnya, makna. Dengan demikian, terdapat orientasi metodologis di dalam 
fenomenologi kehidupan sosial yang berkaitan dengan relasi antara pemakaian bahasa dengan objek-objek pengalaman. Femnomenologi sosial Schutz dimaksudkan untuk merumuskan ilmu sosial yang mampu menafsirkan dan menjelaskan tindakan dan pemikiran manusia dengan cara menggambarkan struktur-struktur dasar, realita yang tampak di mata setiap orang yang berpegang teguh pada sikap alamiah.

\section{Temuan Penelitian}

\section{Makna Perkawinan Masyarakat adat Saibatin}

Perkawinan adalah sebuah gerbang untuk membentuk keluarga bahagia. Hal ini ditegaskan dalam Undang-Undang Nomor 1 tahun 1974 tentang perkawinan. Pada pasal 1 disebutkan bahwa perkawinan ialah ikatan lahir batin antara laki-laki dan perempuan sebagai suami-isteri dengan tujaun untuk membentuk keluarga yang bahagia dan kekal berdasarkan ketuhanan yang maha esa. (Koentjraningrat:2005:58) perkawinan merupakan peralihan dari tingkat hidup remaja ke tingkat hidup berkeluarga. Sementara itu, Usman Adji dalam Winanto (2010:15) menjelaskan bahwa perkawinan dalam masyarakat biasanya mengikuti perkawinan menurut hukum adat, yaitu urusan keluarga; anak-anaknya melepaskan diri darinya segera atau dalam waktu tertentu, kemudian setelah mereka melakukan perkawinan, mereka menlanjutkan hidup orang tuanya atau salah seorang diantara orang tuanya.

Di Indonesia mengenal beberapa bentuk perkawinan pada masyarakat adat. Hal ini bertujuan untuk mempertegas kedudukan, status serta peran dan tanggung jawab setelah melakukan perkawinan. Menurut Hadikusuma dalam bukunya Hukum Perkawinan Adat (1995) dikutip Winanto (2010:19) perkawinan adat terdiri dari (1) perkawinan Jujur, yaitu perkawinan yang dilakukan secara jujur atau terang-terangan. Perkawinan ini ditandai oleh kedua belah pihak yang terbuka dan adanya penyerahan uang dan barang-barang dari pihak keluarga laki-laki kepada pihak perempuan. Dengan diterimanya uang dan barang tersebut 
berarti setelah perkawinan, calon mempelai perempuan ikut pulang atau mengalihkan kedudukan dari kerabat orang tuanya kepada kerabat calon suaminya. (2) Perkawinan Semanda, bentuk perkawinan tanpa ada pembayaran uang jujur dari pihak laki-laki kepada pihak perempuan. Usai perkawinan, mempelai laki-laki ikut pulang ke rumah mempelai perempuan dan masuk ke dalam kekerabatan istri serta meneruskan keturunan dari pihak istri. Perkawinan Semanda semua kewenangan ada pada pengaruh isteri dan kerabatnya. (3) Perkawinan Mentas, perkawinan dimana kedudukan suami istri dilepaskan dari tanggung jawab orang tua atau keluarga dari kedua belah pihak. Orang tua sifatnya hanya memberikan restu dan membantu dengan memberikan harta warisan jika ada. Masyarakat Saibatin mempunyai istilah lain tentang perrkawinan Mentas yaitu perkawinan Raja-Raja.

Masyarakat Saibatin Lampung tidak memberikan batasan tentang siapa saja yang diperbolehkan dan tidak untuk dipersunting. Mereka sangat terbuka, memberikan kesempatan menikah dengan di luar masyarakat adatnya, bahkan menikah antar etnis. Meskipun sebelumnya masyarakat adat Saibatin terkenal sangat aristokratis dalam hal perkawinan, namun saat ini relatif lebih demokratis. Setiap anggota masyarakat adat diperbolehkan menikahi antar suku, etnis selama tidak melanggar ketentun agama. Masyarakat adat Saibatin dalam menerapkan adat istiadat seringkali mengembalikan kepada ajaran agama. Mereka dikenal sangat religius dalam tatanan kehidupan sehingga memahami budaya sangat dinamis. Koentjaraningrat (2005:58) dalam bukunya Pengantar Antropologi; Pokok-Pokok Etnografi menjelaskan tentang pembatasan jodoh dalam perkawinan meliputi adat eksogami yaitu menentukan bahwa seseorang hanya boleh menikah di luar batas lingkungannya sendiri. Artinya adat eksogami melarang menikahi orang-orang yang ada di dalam satu lingkungan, seperti sesama marga, sesama suku dan lainnya. Lawan dari adat eksogami yaitu endogami, artinya larangan menikah dengan warga dari desa, marga atau suku lainnya. Endogami biasanya digunakan oleh adat Batak Toba, menganggap perkawinan harus dengan Pariban-nya atau anak dari saudara pria ibunya. Sedangkan untuk masyarakat adat Saibatin, menggunakan adat pembatasan jodoh eksogami dan endogami. Terkadang mereka menikah dengan keluarga yang memiliki 
kesamaan dalam status adat dan seringkali pula perkawinan terjadi dalam kondisi eksogami atau di luar status gelar adat maupun suku. Akhir-akhir ini eksogami yang lebih menjadi trend dalam perkawinan adat Saibatin. Mereka tidak membatasi bahkan memberikan keleluasaan dalam menentukan pendamping hidupnya.

Peroses perkawinan adat Saibain dikenal dengan istilah Nayuh. Prosesi diawali dari upacara sakral akad nikah; ijab kabul. Ngekuk; istilah makanan khas pengantin perempuan yang disajikan pada acara Manjau Maju atau berkunjung untuk bertemu dengan pengantin. Nyanik Kubu; membuat persiapan tempat mengolah makanan atau memasak atau tenda bagi masyarakat yang akan membantu memasak. Nyanik Tungku; membuat alat tempat memasak. Nyanik Melegai; membuat dekorasi pelaminan. Bukhakhedaian; mendekorasi rumah pengantin berupa hiasan dinding dari susunan kain panjang. Ngakuk Kemunduk; menggambil buah nangka muda untuk dimasak oleh para ibu-ibu. Kapisang dan Kalapa; mengumpulkan pisang dan buah kelapa sebagai keperluan konsumsi upacara perkawinan. Kahebos, Nyakak Hebos; mencari daun kelapa muda untuk dibuat sebagai tempat makanan penganan khas. Ngelepot Napai, Majak Lepot; membuat makanan khas dari beras ketan yang dibungkus oleh hebos atau daun kelapa muda tersebut. Daduaian; arak-arakan pengantin dari rumah Punyimbang adat yang dituakan hingga ke rumah pengantin untuk melanjutkan prosesi Ngahantok; duduk bersama untuk mendengarkan prosesi Nettah-Adok atau penyampaian dan penyematan gelar adat atau Juluk Adok. Semua rangkaian tersebut dilakukan secara khidmat. Setiap tahap mengandung banyak makna yang secara keseluruhan tergambarkan pada lima sifat masyarakat Lampung yaitu Piil-Pusanggikhi; memegang teguh harga diri. Nemui-Nyimah; ramah terbuka. Nengah-Nyampokh; pandai bergaul. Sakai-Sembaian; suka bergotong-royong dan Juluk-Adok; gelar adat sebagai cerminan sikap dan perilaku. Ke-lima sifat tersebut dijadikan sebagai simbol pada salah satu artifak perkawinan yaitu "Siger atau Segokh" merupakan atribut yang dikenakan di kepala mempelai perempuan.

\section{Konstruksi Makna Status Perkawinan Nyakak}


Nyakak merupakan status perkawinan masyarakat adat Saibatin yang menempatkan posisi perempuan mengikuti jalur kekerabatan laki-laki atau keluarga dari suaminya atau sistem kekerabatan Patrilineal. Setelah menikah secara otomatis terjadi peralihan peran dan tanggungjawab yang sebelumnya dikuasai oleh keluarga isteri kemudian berpindah kepada keluarga suami. Secara tidak langsung pada perkawinan Nyakak menempatkan perempuan dalam posisi diambil atau ambil anak, anak perempuan dibeli oleh keluarga laki-laki, bersamaan dengan penyerahan sejumlah uang serta barang yang dibutuhkan oleh keluarga perempuan. Status perkawinan Nyakak, merupakan salah satu bentuk wacana tentang gender yaitu menjadikan laki-laki atau perempuan atau jenis kelamin sebagai sesuatu objek yang dikaji. Salah satu asumsi teori sikap feminis atau Feminis Standpoint Theory Chafetz dalam Turner (2008:187) menekankan bahwa jenis kelamin atau gender merupakan fokus utama teori feminis. Teori ini memandang bahwa jenis kelamin merupakan masalah atau problematik yang seringkali terjadi dimasyarakat.

Topik atau wacana gender juga muncul dan dikembangkan oleh Lakoff (1975). la melakukan kajian tentang perempuan dan posisinya. Studi ini muncul dari gerakan perempuan pada tahun 1970 -an. Feminis menyimpulkan bagaimana bahasa, baik struktur dan pola penggunaan, dianggap sebagai keyakinan dominan tentang inferioritas perempuan. Lakoff melalui tulisannya berjudul Language and Womens Place yang dikutip dalam The Concise Encyclopedia of Communication, Lakoff berpendapat bahwa Womens and Place menggambarkan perempuan sebagai makhluk manis, ragu-ragu, dan lemah. Status perempuan juga dianggap sebagai status sekunder. Sebuah wacana yang masih diperdebatkan tentang apakah bahasa hanya mencerminkan ketidaksetaraan gender atau bahasa juga digunakan sebagai bentuk dari diskriminasi berbasis seks atau jenis kelamin.

Kajian Lakoff tentang gender tersebut sangat relevan dengan kondisi yang terjadi pada masyarakat adat Saibatin Lampung. Mereka yang secara turun-temerun kental dengan adat istiadatnya, meyakini budaya warisan sebagai sesuatu yang harus dilestarikan termasuk tentang status perkawinan Nyakak. Sujadi (2013:21) masyarakat adat Lampung 
yang terdiri dari suku adat Saibatin dan suku adat Pepadun, memang memiliki falasafah hidup yang sama akan tetapi pada pelaksanaan dan pemahaman adat istiadat kecenderungan ada yang berbeda. Saibatin sangat kental dengan sifat aristokrasinya dalam memandang status perkawinan, sedangkan suku adat Pepadun lebih bersifat demokratis. Meskipun saat ini Saibatin juga sudah mengikuti perkembangan dalam menetapkan status perkawinan.

Nyakak sebagai status perkawinan, dipilih ketika kondisi menghendaki perempuan harus mengikuti keluarga laki-laki. Hal ini terjadi karena keluarga perempuan dinilai tidak jauh lebih baik secara status sosial jika dibandingkan dengan keluarga laki-laki. Faktor selanjutnya karena laki-laki tersebut merupakan anak pertama dari keluarganya sehingga ia diposisikan sebagai penerus keturunan dan adat istiadat keluarga. Nyakak juga terjadi pada saat keluarga perempuan tidak merestui hubungan mereka sehingga terjadi perkawinan Sebambangan (dilarikan) oleh keluarga laki-laki. Artinya dari beberapa faktor terjadinya status perkawinan Nyakak, tetap menempatkan perempuan sebagai kelompok atau kelas kedua. Lakoff (1975) menekankan bahwa dalam situasi seperti ini perempuan sebagai kelompok yang berada pada status sekunder atau nomor dua setelah laki-laki. Feminis Standpoint Theory atau teori sikap feminis Chafetz dalam Turner (2008:187) menekankan bahwa hubungan jenis kelamin atau gender dipandang sebagai sesuatu yang problematis, dan teori ini berusaha untuk memahami bagaimana jenis kelamin atau gender berhubungan dengan ketidak-adilan dan kontradiksi. Hubungan jenis kelamin atau gender dipandang sebagai sesuatu yang dapat diubah. Teori feminis dapat digunakan untuk menantang status qua ketika status qua ini merendahkan atau melecehkan perempuan.

Ragam asumsi teori feminis merupakan landasan bagaimana peneliti mengkonstruksi makna yang terkandung dalam status perkawinan Nyakak. Berdasarkan asumsi teori feminis teresebut, perempuan sangat jelas memiliki posisi yang berbeda pada perkawinan Nyakak. Terlepas bahwa Lampung memang menganut sistem kekerabatan Patrilinial, akan tetapi status perkawinan Nyakak memang mengandung makna bahwa 
perkawinan layaknya seperti "transaksi perkawinan" artinya pihak keluarga laki-laki meminta dan mengambil pulang anak perempuan yang akan dijadikan sebagai isteri dari putranya. Perempuan Nyakak, bertanggung jawab penuh terhadap kekerabatan suami dan adat istiadat serta apapun yang melekat pada keluarga suaminya. Isteri dengan status Nyakak juga mengandung makna bahwa perempuan adalah individu yang lemah dan tidak berdaya. Isteri harus mengikuti semua aturan yang ditetapkan oleh keluarga suami. Sejak itu pula isteri sangat tabu dan akan menjadi aib bagi kedua keluarga apabila pulang ke rumah orangtua kandung atau asalnya (istilah lampung: niyuh) tanpa se izin dari suami. Isteri yang sudah diambil oleh keluarga suami maka dipandang tidak memiliki tempat lagi di dalam keluarganya. Jika ia datang ke rumah orang tuanya, maka suadara kandungnya adik atau kakaknya memandang sebagai tamu yang datang dan menumpang. Hal ini memperkuat konstruksi tentang makna bahwa perempuan yang telah memutuskan menikah Nyakak, menjadi tabu apabila kembali lagi ke dalam keluarga kandungnya. Perempuan menikah Nyakak juga dinilai tidak memiliki hak untuk keluarga besarnya dan tidak mempunyai kewajiban pula untuk membantu kesulitan yang dialami oleh orang tua kandungnya sekalipun. Perempuan Nyakak dapat memberikan bantuan apabila seizin suami dan keluarga besar suami.

Sikam si Nyakak-je sebenokhne gegoh gaoh injuk dibeli anggihne keluarga kajong ulih setelah perkawinan pihak keluarga bakas sepenuhne berhak atas bebai sai diakuk jadi mantune. Sikam bebai yu haga khepa gelakhne adat istiadat kham Lampung jak tumbai-tumbaine. Nyakak khetine mulang mit lamban balak ni kajong kham, jadi bebai si Nyakak bertanggung jawab penuh atas keluarga besar kajong kham termasuk kekerabatan khek adat istiadatne.

Kami kaum perempuan yang memutuskan untuk menikah dengan sistem Nyakak, sebenarnya sama seperti dibeli oleh keluarga calon suami karena setelah menikah pihak laki-laki berhak dan memiliki sepenuhnya atas diri perempuan yang akan dijadikan menantunya. Kami kaum perempuan tidak bisa berbuat apa-apa karena ini 
sudah menjadi adat istiadat orang Lampung dari zaman dahulu. Nyakak artinya ikut pulang ke rumah calon suami, jadi perempuan yang Nyakak bertanggung jawab penuh atas keluarga besar dari suami termasuk tentang kekerabatan dan adat istiadatnya. (Informan E: 27 April 2015).

Perempuan yang memutuskan untuk Nyakak, setelah menikah menggantikan posisi sebagai jukhagan lamban (tuan rumah) dari ibu mertuanya. Semua peran dan tanggung jawab yang sebelumnya ada pada ibu mertua kemudian dialihkan kepada anak menantunya. Mengurus dan mengelola keperluan keluarga termasuk membersihkan dan merawat rumah, mengurus domestik hingga pakaian semua anggota keluarga seperti suami, adik dan mertua. Semua pekerjaan rumah tangga berpindah tangan kepada menantu atau isteri dari suami yang menikah dengan status Nyakak.

Konsekuensi lain dari perkawinan Nyakak adalah mengenai kesiapan ekonomi yang dari pihak keluarga laki-laki. Artinya ketika keluarga laki-laki memutuskan untuk mengambil anak perempuan orang lain, seiring itu pula keluarga laki-laki bertanggung jawab penuh terhadap keberlangsungan ekonomi anak menantunya. Hal ini dilakukan sejak persiapan biaya untuk upacara perkawinan hingga setelah perkawinan selesai. Pihak keluarga laki-laki, orang tua mertua dapat meyakinkan bahwa sandang, papan dan pangan mencukupi anak menantunya. Adanya warisan berupa rumah serta kekayaan lainnya berupa kebon, sawah, perhiasan dan lainnya. Selain itu, keluarga laki-laki juga harus menyediakan sejumlah uang untuk keluarga perempuan. Besarnya materi yang dipersiapkan oleh keluarga calon suami dalam perkawinan Nyakak, mengandung makna bahwa perempuan atau anak menantu secara insplisit telah berpindah tangan atau terjadi transaksi antara kedua keluarga. Makna lain yang terkandung dalam perkawinan Nyakak bahwa terjadi ketika keluarga laki-laki dipandang lebih mapan dalam ekonomi dibandingkan ekonomi keluarga perempuan. Perkawinan dengan status Nyakak juga memberikan arti bahwa pola budaya keluarga lakilaki sangat dominan. Nilai budaya yang dianut adalah budaya kekuatan laki-laki sebagai individu yang mendominasi atas semua aturan atau kebijakan. 
Merujuk pada nilai dominan dalam suatu masyarakat terorientasi pada laki-laki, Samovar (2010:245) dalam bukunya Komunikasi Lintas Budaya; Communication Between Cultures, mengutip pendapat Hofstede nilai budaya yang ada pada dominasi laki-laki disebut maskulinity. Hofstede menggunakan kata maskulin dan feminine untuk merujuk pada tingkatan dimana sifat maskulin dan feminine dinilai dan dinyatakan. Dasar pemikiran dan salah satu yang didukung oleh kebanyakan antropolog, psikolog dan ilmuan politik, adalah bahwa banyak perilaku maskulin dan feminin yang dipelajari dan dimediasikan oleh norma budaya dan tradisi. Demikian pula yang dialami oleh perempuan dalam status perkawinan Nyakak. Terbangun makna bahwa keluarga laki-laki mendominasi keluarga perempuan. Hal ini dinyatakan atau dipraktikkan ketika status kekerabatan, adat dan apapun yang melekat dapat berpindah tangan dari keluarga perempuan, kemudian ke keluarga laki-laki terhitung setelah status resmi menikah. Misalnya, perpindahan penentuan gelar adat yang akan mengikuti jalur gelar dari keluarga laki-laki.

Norma maupun tradisi yang diyakini oleh masyarakat adat Saibatin tentang status perkawinan Nyakak, tetap dipandang sebagai kearifan lokal ketika nilai-nilai perkawinan Nyakak tersebut dimaknai sebagai hal yang bermanfaat. Misalnya, sebagai bentuk kepatuhan terhadap adat istiadat dan keberlangsungan perkawinan adat di masyarakat adat Saibatin Lampung.

\section{Konstruksi Makna Status Perkawinan Semanda}

Masyarakat adat Saibatin selain mengenal status perkawinan Nyakak juga memilih perkawinan Semanda. Perkawinan ini menekankan bahwa laki-laki yang menikah Semanda dengan sadar dan rela untuk mengabdikan diri kepada keluarga isteri. Setelah menikah lakilaki ikut pulang ke rumah keluarga perempuan. Perkawinan Semanda merupakan perkawinan yang terjadi ketika keluarga perempuan menghendaki puterinya untuk menjadi ahli waris atau peneruas keluarga, kekerabatan dan adat istiadat orangtuanya. 
Makna yang terkandung dalam perkawinan Semanda yaitu keluarga perempuan dipandang lebih memiliki kekuatan dibandingkan keluarga laki-laki. Kekuatan dalam segala hal seperti kekuatan ekonomi, status adat dan posisi anak perempuan yang menjadi tumpuan atau panutan keluarganya. Perkawinan Semanda terjadi karena beberapa faktor, selain karena ekonomi juga faktor turunan, artinya ketika semua anggota keluarganya berjenis kelamin perempuan sehingga salah satu dari anak perempuannnya wajib menikah dan mencari laki-laki yang siap untuk dibawa pulang sebagai pewaris dan penerus jalur kekerabatan dari pihak isteri atau matrilineal.

Perkawinan Semanda dan Nyakak memang sangat kental dipengaruhi oleh faktor ekonomi. Hal ini yang menjadi pengaruh kekuasaan yang dominan bagi kedua status perkawinan tersebut. Semanda mengandung makna bahwa kekuasaan yang paling dominan ada pada keluarga perempuan. Sama halnya dengan perkawinan Nyakak, laki-laki yang Semanda bertanggung jawab penuh dalam mengelola harta warisan dari mertua untuk isteri dan anak-anaknya. Namun, ia tidak berhak untuk mengambil kebijakan apalagi memutuskan setiap kondisi yang terjadi, terutama hal yang terkait dengan harta warisan. Jika ada polemik tentang harta warisan maka yang berhak memutuskan adalah keluarga perempuan. Laki-laki yang Semanda hanya memiliki wewenang dalam mengelola warisan sebagai sarana untuk menghidupi keluarga perempuan. Biasanya laki-laki Semanda yang mendapatkan mandat dari mertua untuk mengolah tanah warisan atau tanoh pusako. Lakilaki yang Semanda juga diharapkan dapat membimbing, mengemong isteri dan anakanaknya. Artinya, tugas utamanya adalah melindungi keluarga dari segala ancaman maupun situasi yang tidak nyaman.

Semanda vs Nyakak memiliki substansi yang sama yakni menempatkan faktor gender pada persoalan menentukan status perkawinan. Hal itu berimplikasi terhadap otoritas dan dominasi serta kekuatan yang dimiliki atas masing-masing status perkawinan. Jika perkawinan Semanda memiliki makna bahwa perempuan yang mendominasi semuanya. Hal ini serupa yang dijelaskan oleh Hofstede dikutip oleh Samovar (2010:245) 
bahwa budaya yang menghargai nilai feminine sebagai sifat yang menekankan perilaku yang mengemong. Pandangan feminine menyatakan bahwa laki-laki tidak perlu tegas dan bahwa perempuan juga dapat mengemong seperti laki-laki. Feminin juga mendukung keadilan gender.

Perkawinan Semanda mengandung konsekuensi bahwa setelah menikah semua pertalian kekerabatan dan adat istiadat berpindah kepada pihak keluarga isteri. Demikian pula jalur gelar adat yang disandangnya. Sedangkan konsekuensi secara ekonomi, keluarga perempuan harus memastikan bahwa anak menantu yang dibawa pulang semua kebutuhan dan keperluannya tercukupi. Sama halnya dengan perkawinan Nyakak, semua materi mulai dari persiapan hingga setelah perkawinan menjadi tanggungan keluarga yang memutuskan status perkawinan. Jika Semanda maka keluarga perempuan atau isteri yang bertanggung jawab, demikian sebaliknya.

Persiapan materi yang diperlukan setelah menikah biasanya meliputi sandang, pangan dan papan. Mulai dari hal terkecil seperti keperluan rumah tangga seperti perabotan rumah hingga pada fasilitas berupa rumah dan harta warisan yang dapat difungsikan sebagai mata pencaharian seperti kebun dan sawah. Lalu bagaimana dengan kondisi keluarga yang secara kekuatan dipandang sama mampu atau tidak mampu dalam hal ekonomi? kedua keluarga memiliki prinsip bahwa status perkawinan Raja-Raja adalah pilihan yang tepat. Status perkawinan Raja-Raja, yaitu perkawinan yang menempatkan posisi ditengah atau diantara kedua keluarga. Tidak ada yang paling berhak atau merasa memiliki, akan tetapi keduanya mempunyai hak dan tanggung jawab yang sama besarnya. Oleh karena itu, biasanya pada perkawinan Raja-Raja ini terjadi ketika anak tersebut berstatus anak tunggal, anak pertama dan ekonominya dipandang sama. Perkawinan RajaRaja terjadi pula karena perbedaan etnis. Koentjaraningrat (2005:97) menyebut istilah RajaRaja sebagai sistem perkawinan dengan prinsip keturunan sejajar atau bilinial atau double descent. 
Status perkawinan Raja-Raja saat ini salah satu alternatif yang dijalani oleh sebahagian anggota masayarakat adat Saibatin. Mereka memutuskan hal ini sebagai bentuk penyesuaian terhadap kondisi dan perubahan zaman. Saat ini, perempuan-perempuan di daerahpun termasuk perempuan adat Saibatin, merasa bahwa mereka memiliki hak dan tanggung jawab yang sama sehingga mereka tidak ingin terkait oleh atau diantara keluarga dari status perkawinan. Perkawinan Raja-Raja sebagai salah satu solusi ditengah dominiasi antara keluarga laki-laki dan perempuan atau keluarga suami dan isteri. Menurut Chafetz dalam Turner (2008:187) teori sikap feminis menekan bahwa hubungan jenis kelamin atau gender dipandang sebagai sesuatu yang dapat diubah. Teori feminis dapat digunakan untuk menantang status qua ketika status qua ini merendahkan atau melecehkan perempuan. Hal ini pula yang terkesan dalam makna perkawinan Raja-Raja masyarakat adat Saibatin. Para orang tua yang sebelumnya sangat aristokratik dalam memutuskan status perkawinan, berubah menjadi lebih demokratis. Sudah jarang ada orang tua yang memaksakan status perkawinan sekalipun memandang keluarganya lebih mampu. Perempuan masyarakat adat Saibatin, mencoba untuk melepaskan diri dari kekuasaan atas dirinya sebagai akibat dari status perkawinan yang dipilih. Demikian pula kelompok laki-laki, tidak ingin dianggap sebagai pribadi yang tidak dapat berdiri sendiri sehingga memilih status perkawinan RajaRaja, untuk membuktikan bahwa melalui usaha sendiri ia dapat menghidupi keluarganya. Makna lain dari perkawinan Raja-Raja yang saat ini menjadi trend, menekankan bahwa gender tidak dapat dijadikan sebagai hal yang substantif dalam status perkawinan. Akan tetapi yang menjadi penekanan adalah kesiapan dari setiap anak yang akan menentukan keberlangsungan rumah tangganya dikemudian hari.

\section{Konstruksi Struktur Diri Perempuan Nyakak dan Laki-Laki Semanda}

Status perkawinan Nyakak vs Semanda merupakan perkawinan sistem adat Saibatin Lampung. Tidak banyak orang mengetahui tentang hal ini, sehingga makna-makna yang melekat di dalamnya pun tidak cukup populer. Namun, bagi masyarakat adat Saibatin, hal 
itu sudah menjadi kebudayaan, lahir sebagai sistem nilai keyakinan sehingga sampai saat ini masih lestari di masyarakat adat Saibatin Lampung.

Perkawinan Nyakak vs Semanda memang dilatar belakangi oleh beberapa alasan utama, seperti mencari kehidupan yang lebih baik, bahkan status sosial dan penghargaan masyarakat. Didorong oleh tujuan tersebut seringkali individu yang akan lapah (berangkat) memilih Nyakak vs Semanda selalu mempertimbangkan materi. Jika dipandang tidak dapat menjanjikan kehidupan yang lebih baik maka tidak sedikit memilih mundur dan mencari pasangan lainnya. Hal ini seperti yang diakui oleh informan yang mengakui sebagai perempuan berstatus perkawinan Nyakak.

Haga nyepok kehokhekan, kedudukan, kelajuan hokhek ki mak ngedok sitibidak haga api, bacak da mekekh khua kali...hehehehe... (ingin mencari kehidupan, kedudukan serta masa depan yang lebih baik. Apabila tidak ada yang diharapkan untuk apa lebih baik mikir dua kali..hehehehe: Informan E: wawancara 27 April 2015).

Perempuan Nyakak dan laki-laki Semanda juga menganggap bahwa dirinya membutuhkan penghargaan, pengakuan dan penghormatan oleh keluarga suami atau isteri. Sebagai individu berstatus orang asing (jekhma khatong) akan tetapi diposisikan sebagai raja atau ratu di dalam rumah orang tua mertuanya. Raja dan Ratu dalam artian bukan orang yang dilayani akan tetapi dihormati dan disegani oleh anggota keluarga suaminya. Sedangkan untuk peran dan tanggung jawab, perempuan Nyakak wajib mengelola rumah tangga keluarga besar suami dan melakukan pekerjaan rumah tangga. Sedangkan untuk orangtua mertua sebagai orantua pengganti dari orangtua kandungnya yang harus dilayani dan dihormati. Semua urusan pengelolaan rumah tangga yang sebelumnya dipegang oleh ibu mertua dan ayah mertua kemudian diambil alih oleh anak menantunya. Meskipun mereka secara status adalah orang asing, namun setelah menjadi menantu statusnya tidak berbeda dengan anak kandung bahkan lebih tinggi dari itu. Keberadaan dirinya sangat dihormati oleh anggota keluarga iparnya. Bahkan sesuatu yang 
tidak didapatkan sebelumnya dari orang tua kandungnya, kemudian diperoleh dari keluarga iparnya. Hal ini yang menjadi alasan anak menantu atau saudara ipar atas status perkawinan ini menjadi lebih tersanjung dan merasa dihargai. Semakin tinggi pengakuan dan penghargaan dari keluarga suami atau isterinya, maka akan berbanding lurus dengan rasa tanggung jawabnya terhadap keluarga suami atau isteri.

Yuu sikam sebagai jekhma khatong memang harus tau diri, tapi saya juga wat hak supaya dihakhgae, diakui anggihne keluarga besar kajong kham. Ki tian mak ngedok penghargaan, pengahut haga api saya ngabdi, ngukhuskko unyinne kepekhluan ahli puakhi jak kajong kham... (Ya sebagai orang pendatang masuk ke dalam keluarga suami atau isteri memang harus tau diri, tapi saya juga memiliki hak agar dihargai, diakuo oleh keluarga besar suami. Apabila mereka tidak memberikan itu, tidak ada tanda kasih sayang, untuk apa saya mengabdikan diri, mengurus semua keperluan keluarga besar suami. Wawancara informan E: 27 April 2015).

Status perkawianan Nyakak vs Semanda diakui sebagai wujud kebanggan dan kepuasan pribadi. Menurut pengakuan informan, makna yang terkandung dalam status perkawinan mereka, yakni sebagai bentuk status sosial ditengah masyarakat internal adat maupun eksternal. Misalnya mencari calon suami atau isteri dari keluarga Punyimbang atau pemangku gelar adat yang peran dan fungsinya lebih baik dibandingkan keluarganya. Lakilaki Semanda dan perempuan Nyakak sangat bangga apabila mendapatkan anak dari seorang Punyimbang gelar adat seperti Sebatin, Khaja dan Raden apalagi Sultan. Mereka merasa harkat dan martabat terangkat ketika menjadi isteri dari seorang Punyimbang gelar adat Raden meskipun secara ekonomi biasa saja. Kebanggaan ini seiring dengan penghormatan dan penghargaan yang diterimanya dari anggota masyarakat adat. Masyarakat adat Saibatin Lampung, meskipun tidak menempatkan gelar adat sebagai status sosial, hiraki sosial atau gelar kebangsawanan, akan tetapi secara insplisit pada setiap peristiwa komunikasi terkandung beberapa makna yang mempertegas adanya tingkatan gelar adat sebagai status sosial adat. Hal itu dirasakan pada saat suasana komunikasi yang 
dibangun dalam setiap peristiwa. Mulai dari penggunaan bahasa, lokasi atau posisi pada setiap pusat keramaian seperti pada waktu pernikahan. Semua disetting secara alamiah dan terbentuk sesuai kesadaran akan gelar adat yang disandangnya. Untuk setiap setting komunikasi, gelar adat sangat mempengaruhi peran dan fungsinya. Oleh karena itu, sangat wajar apabila individu yang memilih status perkawinan Nyakak vs Semanda juga merasa bahwa dirinya terobsesi terhadap gelar adat keluarga suami atau isterinya.

Khasane khepa khena kidapok ngajongko anakne Raden, kham jadi jukhagan pemekonan, wat anak buah si dapaok dikayun, kham tinggal ngontrol khek ngarahkone gaoh. Khek moneh secara sosial kham lebih dihakhgae, terutama pas lagi wat khekhamikkan. (Rasanya bagaimana gitu klo mendapatkan pasangan dari keturunan gelar adat Raden, kita diposisikan sebagai tuan rumah bagi keluarga mertua dan mendapatkan penghormatan dari anggota masyarakat adat. Menjadi orang yang berperan dalam urusan adat dan kita juga mempunyai orang-orang yang siap membantu sebagai tangan kanan sehingga secara status sosial dimasyarakat akan kita lebih dihargai, terutama pada saat ada keramaian adat). Wawancara informan E: 27 April 2015).

Menikah dengan menyandang status Nyakak vs Semanda diakui bukan sebuah aib atau keterpaksaan, akan tetapi telah menjadi kesepakatan adat meskipun dalam menentukan status tersebut tidak melibatkan orang lain. Hal ini diakui sebagai wilayah khusus internal antara kedua keluarga yang akan menikahkan putra dan putrinya. Bahkan dari sejak awal seperti pada masa mencari pacar atau masa pacaran masing-masing sudah menentukan kriteria calon suami atau isterinya. Dari awal pula secara sadar masing-masing sudah memprediksi dan merencanakan status perkawinan mereka. Artinya sudah mengukur kemampuan diri dan keluarga (khumasa) atau tau diri. Jika memang keluarganya tidak mampu dari segi ekonomi, jangan pernah bermimpi untuk mengambil anak orang. Misalnya bagi perempuan yang tau kemampuan keluarganya, maka biasanya ia lebih memilih keluar rumah dan ikut pulang ke rumah calon suaminya atau Nyakak. Demikian 
pula bagi seorang laki-laki, ia biasanya tau diri sejak awal. Apabila dalam keluarganya ia memiliki saudara laki-laki, maka sebagai adik ia lebih baik memilih status perkawinan Semanda. Sejak awal pula ia mencoba mencari pacar dari keluarga yang dinilai dapat memberikan kehidupan dan masa depan bagi dirinya. Mencari anak perempuan dari keluarga dan keturunan yang lebih dari keluarganya.

Status Nyakak vs Semanda diakui sebagai sebuah proses pertukaran posisi, peran dan tanggung jawab. Jika sebelumnya selama masih lajang tetap memiliki hak atas apa yang dimiliki orangtuanya. Maka setelah menikah dan mengikuti status perkawinan, maka peran dan tanggung jawab pindah kepada keluarga suami atau isteri. Mulai dari hak-hak yang selama ini ia dapatkan dari orangtua kandung akan tergantikan bahkan melebihi yang diperloh dari bapak-ibu mertuanya. Terjadi pertukaran posisi yang semulanya menjadi tuan rumah di rumah orangtua kandung, kemudian berubah menjadi tuan rumah di keluarga mertuanya. Dengan demikian, keluarga kandung atau keluarga asalnya menjadi keluarga kedua menyusul terjadinya perubahan dan pertukaran status keduanya. Keutamaan dan tanggung jawab berpindah kepada keluarga suami bagi isteri yang Nyakak dan berpindah ke keluarga isteri bagi suami yang Semanda. Secara adat status perkawinan Nyakak dan Semanda menempatkan diri pada situasi ambil anak orang lain untuk dijadikan sebagai anak menantu sehingga peran dan tanggung jawab sebelumnya berpindah dan mengikuti kekerabatan dari keluarga barunya. Informan N sebagai laki-laki yang menjalani perkawinan Semanda mengakui:

Bakas Semanda gegoh gaoh tetok ulih secakha adat sikam Semanda dilebonko, ulih api? karena peran khek tanggung jawab sekhta hak sikam mangedok lagi di keluarga kandung kham. Sikam mak dapok ikut campur lagi jama keluarga kandung apipun bentukne. Semanda gegoh gaoh lapah malih pindah jenganan nutuk keluarga bebai kham. (Wawancara: 1 Mei 2015).

Laki-laki Semanda sama saja seperti dibuang secara adat, dihilangkan dari keluarga aslinya karena orang Semanda tidak ada lagi peran, tanggung jawab dan hak 
terhadap keluarga kandungnya. Tidak dapat ikut campur lagi dalam segala hal. Semanda sama saja pergi jauh dan pindah tempat tinggal mengikuti keluarga istri.

Perempuan Nyakak vs Semanda memposisikan dirinya sebagai tamu ditengah keluarga kandungnya. Bahkan mereka memandang dirinya sebagai orang luar sehingga tidak memiliki hak untuk ikut campur terhadap urusan kekarabatan maupun tentang adat dan warisan orangtua kandungnya. Jika pun diminta saran hanya sekedar saran dan membantu bukan mengambil kebijakan apalagi yang memutuskan. Demikan pula bagi lakilaki yang Semanda, ia menyadari posisi dan perannya saat itu telah berganti dan pindah kepada kelurga isterinya. Namun, di keluarga suami atau isterinya tersebut orang yang Nyakak dan Semanda menjadi tuan rumah atau Jukhagan Lamban atau orang yang berkuasa di dalam rumah mertuanya. Bahkan saudara ipar harus menghormati sekalipun ia adalah orang yang lain yang diambil menjadi kakak ipar. 

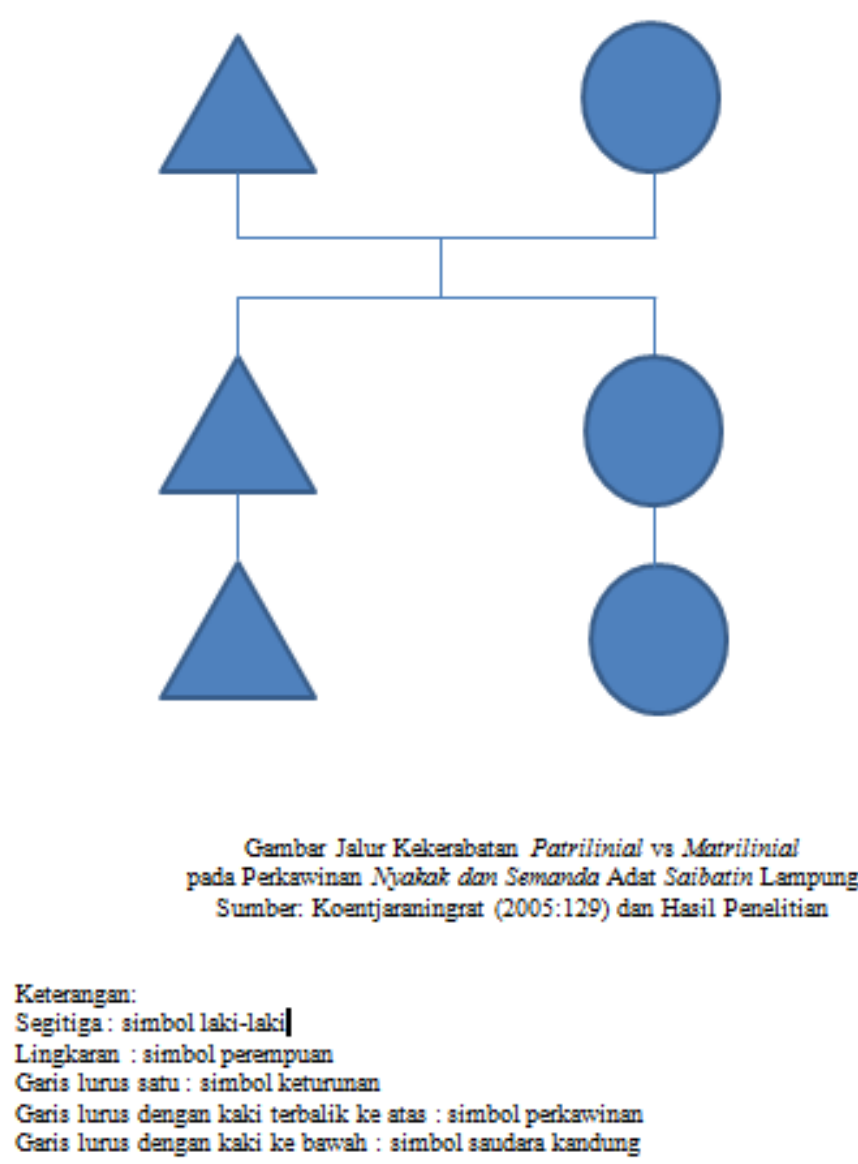

Dampak yang menonjol selain terjadinya perubahan pada jalur kekerabatan patrilinial atau matrilinial, perkawinan status Nyakak vs Semanda, juga memunculkan labelabel atau sebutan menyusul terjadinya perubahan pada posisi, peran dan fungsi keluarga. Label sebagai pendatang atau tamu bagi keluarga kandungnya. Label seagai orang datang (jekhma khatong) di keluarga suami. Oleh karena itu, segala tindak tanduk, sikap dan perbuatan sangat mempertaruhkan label yang secara tidak langsung telah disandangnya. Laki-laki Semanda maupun perempuan Nyakak, akan menjadi bahan perbincangan bahkan aib keluarga kandungnya apabila tidak dapat menjalankan peran dan tanggung jawabnya sebagai individu yang memikul status perkawinan. 
Memahami makna bahwa dirinya berstatus Nyakak vs Semanda juga dirasakan dari sebutan atau panggilan sehari-hari dari anggota keluarga barunya. Misalnya, adik ipar memanggil kakak iparnya dengan sebutan Kaka, artinya bahwa ia adalah bukan saudara kandung melainkan orang lain yang menjadi saudara karena pertalian pernikahan dengan saudaranya. Kemudian keponakan dari suami atau isteri akan memanggil dengan sebutan Nik, artinya isteri dari paman yang berasal dari luar keluarga mereka. Sedangkan panggilan lbung khusus untuk adik dari paman kandung. Jika ia menikah dengan status Semanda, maka tetap dipanggil lbung sedangkan suaminya dipanggil dengan sebutan Mamak atau paman.

Laki-laki Semanda dan Perempuan Nyakak disebut sebagai tradisi ambil anak. Koentjoroningrat (2005:103) menjelaskan bahwa tradisi ambil anak di Lampung sama seperti adat Sentana di Bali. Tradisi ini dilakukan dalam masyarakat yang menganut sistem hukum waris diturunkan kepada keturunan laki-laki sehingga setelah menikah mereka harus tinggal dilingkungan keluarga laki-laki atau adat virilokal. Apabila ia hanya memiliki anak perempuan, maka ia boleh mengambil laki-laki untuk dijadikan menantu dan tinggal di rumahnya. Biasanya laki-laki yang diambil tersebut berasal dari keluarga yang kurang berada dan bukan anak tertua atau sulung dari beberapa saudaranya. Di Bali adat ambil anak bagi seorang laki-laki dinilai kurang terhormat, hal ini dilakukan apabila ia terpaksa karena status ekonomi. Sedangkan untuk masyarakat adat Saibatin tidak demikian, justru ia lakukan atas kesadaran penuh (tau-diri) tentang posisi dan situasi dalam keluarganya. Mereka memutuskan status perkawinan berdasarkan musyawarah keluarga dengan pertimbangan kondisi internal keluarga. Kemufakatan terjadi bukan dipaksa akan tetapi mengikuti kebiasaan atau adat istiadat yang sudah menjadi kesepakatan tidak tertulis dan telah dibangun secara turun-temurun.

\section{Hasil Penelitian}

Perempuan Nyakak laki-laki Semanda menempatkan gender sebagai salah satu pertimbangan dalam menentukan status perkawinan, pertalian kekerabatan, gelar adat dan 
adat menetap sesudah menikah. Untuk tataran masyarakat adat Saibatin, status perkawinan apapun yang diambil bukan menjadi aib atau hal yang tercela, namun hal yang diyakini sebagai tradisi adat istiadat perkawinan. Tidak mengenal kelas atau hirarki atau statu sosial sebagai akibat dari status perkawinan. Mereka lebur menjadi satu bahkan diantara mereka memiliki status yang sama. Adat Saibatin juga sangat menghargai ketetapan status perkawinan sebagai wilayah dan kekuasaan pribadi keluarga dan adat tidak dapat ikut campur. Adat berada di posisi netral meskipun status perkawinan tetap disampaikan kepada semua Punyimbang atau pemangku adat untuk ditindak lanjuti, yakni melakukan sidang adat menetapkan gelar adat atau Juluk-Adok yang akan diberikan kepada kedua calon pengantin dan keluarganya. Gelar adat ini menyesuaikan status perkawinan yang dipilih. Apabila status Nyakak maka gelar mengikuti jalur kekerabatan suami (patrelinial). Demikian pula untuk Semanda, mengikuti jalur keluarga isteri (matrilinial). Selain berimplikasi terhadap gelar adat, status perkawinan juga menentukan tempat tinggal setelah menikah, virilokal yaitu menetap di sekitar kediaman suami. Uxorilokal, menetap di sekitar lingkungan isteri dan bilokal, adat menentukan bahwa setelah menikah mereka tinggal di tempat suami pada kondisi tertentu dan di tempat isteri dalam kondisi tertentu pula.

Menikah dengan status Nyakak vs Semanda didasari oleh kesadaran pribadi dan musyawarah keputusan keluarga. Seringkali faktor yang mendorong keputusan adalah ekonomi, kondisi psikologis, jumlah saudara kandung, urutan anak dan kemauan sendiri. Hal ini terjadi secara turun-temurun sehingga apapun status perkawinan yang dipilih mereka sudah mengkondisikan konsekuensi yang dijalani setelah menikah.

Pasangan yang tidak ingin terikat oleh salah satu pihak biasanya memilih status perkawinan Raja-Raja. Mereka menilai bahwa status ini sebagai alternatif diantara status Nyakak dan Semanda. Dengan status Raja-Raja merasa dirinya tidak diambil oleh orang lain atau didominasi oleh salah satu pihak. Status Raja-Raja ini menempatkan pada posisi di 
JURNAL LISKI | Vol. 2. No. 1 | 2016

tengah atau ganda (bilinial) sehingga mereka masih mendapatkan peran dan hak atas keluarga kandungnya. 


\section{Daftar Pustaka}

Denzin, Lincoln. (2012). Hand Book of Qualitative. Jogjakarta: Pustaka Pelajar.

Koentjaraningrat. (2005). Pengantar Antropologi Il; Pokok-Pokok Etnografi. Jakarta: Rineka Cipta.

Lokoff, R (1975). Language and Womens Place. New York: Harper and Row: dalam The Concise Encyclopedia of Communication. 2015: Wiley Blackwell.

Miller, Katherine. (2005). Communication Theories: Perspectives, Processes and Contexts. Secound Edition. USA: McGraw-Hill International Edition.

Samovar, Porter, McDaniel. (2010). Komunikasi Lintas Budaya; Communication Between Culutres. Jakarta: Salemba Humanika.

Sobur, Alex. (2013). Filsafat Komunikasi; Tradisi dan Metode Fenomenologi. Bandung: Rosda.

Sujadi, Firman. (2013). Lampung Sai Bumi Ruwa Jurai. Jakarta: Cita Insan Madani.

\section{Jurnal Ilmiah}

Azima, Hussain, Saad, dkk (2013). The Minangkabau's Customary Land: The Role of "Orang Semenda" in Malaysia and Indonesia. Journal Asian Social Science; Vol. 9, No. 8; 2013. ISSN 1911-2017E-ISSN 1911-2025.

Hidayat, Dasrun. (2014). Representasi Nemui-Nyimah sebagai Nilai-Nilai Kearifan Lokal Lampung; Perspektif Public Relations Multikultur. Jurnal Ilmu Komunikasi Universitas Riau. ISSN 2252-665X. Volume 5 Nomor 1. hlm 90-102.

Winanto, M. Angga. (2010). Kedudukan Istri dala Perkawinan Jujur pada Masyarakat Lampung Pepadun Kebuwayan Subing (Studi di Kampung Terbanggi Besar Kapubaten Lampung Tengah).Skripsi. Fakultas Hukum Universitas Lampung. 


\section{Biography of Authors}

Dasrun Hidayat was born in Lampung, 16 November 1978. He completed his undergraduate in 2004 and Master degree in 2010 at Faculty of Communication Science, University of Padjajaran. He is in the process of completing his Doctoral degree at the same university. He is the Head of study program of Communication Science, Faculty of Communication Science at University of BSI Bandung. He has published one book: Komunikasi Antar Pribadi and two textbooks: Be a Good Communicator and Media Public Relations. He is actively involved in researches on cultural study, cultural public relations, and new media with interpersonal communication perspective. 